\title{
Using Anti-Müllerian Hormone (AMH) as a Predictor of Ova Production for Bovine Embryo Transfer
}

\author{
J. T. Jaques ${ }^{1,2}$, R. C. Cardoso ${ }^{1}$, J. Chachere ${ }^{1}$, S. Sinha ${ }^{3}$, R. Seery ${ }^{2}$, A. A. Wilkes ${ }^{4}$, D. Forrest ${ }^{1}$, C. R. Looney ${ }^{*}$ \\ ${ }^{1}$ Department of Animal Science, Texas A\&M University, College Station, TX, USA \\ ${ }^{2}$ Applied BioSciences, College Station, TX, USA \\ ${ }^{3}$ Department of Statistics, Texas A\&M University, College Station, TX, USA \\ ${ }^{4}$ Department of Biology, Texas A\&M University, College Station, TX, USA \\ ${ }^{5}$ University of Arkansas System, Division of Agriculture, Cooperative Extension Service, Southwest Research and Extension \\ Center, Hope, AR, USA \\ Email: ${ }^{*}$ clooney@uaex.edu
}

How to cite this paper: Jaques, J.T., Cardoso, R.C., Chachere, J., Sinha, S., Seery, R., Wilkes, A.A., Forrest, D. and Looney, C.R. (2020) Using Anti-Müllerian Hormone $(\mathrm{AMH})$ as a Predictor of Ova Production for Bovine Embryo Transfer. Advances in Reproductive Sciences, 8, 36-47. https://doi.org/10.4236/arsci.2020.81004

Received: November 23, 2019

Accepted: January 5, 2020

Published: January 8, 2020

Copyright $\odot 2020$ by author(s) and Scientific Research Publishing Inc. This work is licensed under the Creative Commons Attribution International License (CC BY 4.0).

http://creativecommons.org/licenses/by/4.0/

\begin{abstract}
The objective of this study was to determine the relationship of anti-Müllerian hormone (AMH) to ova production in various breeds of cattle in an embryo transfer program. Various factors that were evaluated included breed type, age, weight, body condition and flush history as to their influence on total ova recovery. The superovulation regimen called for CIDR (Controlled Internal Drug Release) insertion and a $2 \mathrm{cc}$ injection of Combo ( $25 \mathrm{mg}$ progesterone and $1.25 \mathrm{mg}$ of estradiol per $\mathrm{mL}$ ( $2 \mathrm{cc}$ IM injection)) on day 0. Day 4, FSH treatments were initiated in both $\mathrm{AM}$ and $\mathrm{PM}$ with decreasing amounts over the next four days. Day 6, along with FSH, prostaglandin was given in the AM and PM. On Day 7, a final FSH injection and CIDR removal were done in the AM. This resulted in estrus and AI on day 8 and collection of ova on day 15 . Results were drawn from analyzing 369 animals; Angus $n=25$, Black Brangus $\mathrm{n}=43$, Red Brangus $\mathrm{n}=53$, Brahman $\mathrm{n}=103$, Beefmaster $\mathrm{n}=112$, and Wagyu $\mathrm{n}=33$. Age of donors ranged from 1.6 years to 15.4 years at collection with an average age of 7.16 years of age. Analysis of results demonstrated that age clearly had a significant $(P<0.05)$ effect on the total ova production and that breed did not have a significant influence $(\mathrm{P}>0.05)$ on ova production. More importantly, we observed the total ova production was significantly ( $\mathrm{P}$ $<0.05$ ) associated with the AMH concentration (the greater the AMH concentration, the greater number of ova per flush).
\end{abstract}

\section{Keywords}

AMH, Ova, Superovulation, FSH, Prostaglandin 


\section{Introduction}

In cattle and various other farm animal species, embryo transfer is a method of replicating valuable genetics at an advanced rate of production. While the national average of ova collected per flush in cattle is cited at 10.1, results can range from over 70.0 to 0.0 [1]. Prostaglandins, progestins, and multiple FSH injections (porcine pituitary extracts (FSH)) are all components of a superovulatory regimen. Stimulation injections over several days, semen, and labor are all factors that go into the overall production of ova in a superovulation regimen. With $20 \%$ of donors producing 0.0 ova per flush [2], it would be beneficial to be able to predict which donor females will perform better than others in an embryo transfer program prior to trial and error, thus saving time and money. Variability can be attributed to the cow, season, follicle stimulating hormone regimen, and status of ovarian follicles at the time of initiation of FSH treatment, technical expertise, among other factors not yet identified [2] [3] [4] [5].

In cattle, development of a follicular wave is characterized by the recruitment and synchronous growth of a large number of antral follicles, followed by selection and growth of a dominant follicle and regression of subordinates [6]-[11]. Presence of a dominant follicle not only refrains the next follicular wave emergence but regresses its subordinate follicles [8] [12]. Typical estrous cycles consist of either one or two waves and sometimes 3 waves, with wave emergence detected on Day 0 (day of ovulation) and Day 10, or days 0, 9, and 16 [6] [7] [8] [13].

Folliculogenisis begins in prenatal life with the production of the smallest of four types of follicles, primordial follicles. Females are born with a finite number of primordial follicles that are characterized by a small, non-growing oocyte, without a zona pellucida and surrounded by a single layer of flattened pre-granulose cells that are at a state of meiotic arrest [14] [15] [16] [17]. Once recruited, the granulosa cells become cuboidal and begin replicating, and the primordial follicle develops into a slightly more advanced primary follicle [16] [17]. Primary follicles that continue to be recruited develop into a preantral secondary follicle with two or more layers of follicular cells. The tertiary or antral follicle is formed in the next phase which typically has a 200 to $300 \mu \mathrm{m}$ diameter consisting of three cell layers: theca external, theca interna, and the granulosa cell layer [14] [18]. These follicles are now responsive to FSH through the FSH receptor development on granulosa cells. After antral formation, cattle and human follicles become gonadotropin dependent at about $3-5 \mathrm{~mm}$ in diameter. Antral follicles below this diameter are the pool of small, gonadotropin responsive, Anti-Müllerian hormone (AMH) producing follicles [14] [18]. Although this growing pool of small antral follicles is what most clinicians and scientists reference to as the ovarian reserve, this is not to be confused with the initial number of finite primordial follicles. Antral follicle count (AFC) is used extensively in both human and animal assisted reproductive technologies to aid in the determination of infertility and to aid in prediction of ovarian response to go- 
nadotropin based treatments [18]. Once a superovulatory regimen is initiated, the numbers of small antral follicles are highly correlated to the number of transferrable embryos [3] [19] [20] [21] [22]. Anti-Müllerian hormone, also referred to as Müllerian inhibiting substance (MIS), is produced by ovarian granulosa cells of small antral follicles and therefore is being noted as a useful marker of the antral follicle pool in the early follicular phase [23] [24] [25] [26].

In embryonic development, regardless of gender, amniotes form two separate and distinct genital ducts, the Wolffian and Müllerian. In mammals, the first (Wolffian duct) differentiates into the male reproductive tract, the vas deferens, epididymides and seminal vesicles, whereas the latter (Müllerian duct) develops into the female reproductive tract which consists of the oviducts, uterus and upper third of the vagina [27]. Anti-Müllerian hormone is $140 \mathrm{kd}$ protein and a member of the transforming growth factor (TGF) beta superfamily of growth and differentiation factors [25] [28] [29]. Contrary to other members of the family, which exert a broad range of functions in multiple tissues, the main function of prenatal AMH is to induce regression of Müllerian ducts during male sex differentiation [23] [30]. This occurs in the bovine fetus between 50 and 80 days [31]. Though the role of AMH in the adult male remains unclear, the Sertoli cells' secrete AMH over the lifespan of the animal [32]. During female sexual differentiation, $\mathrm{AMH}$ is not expressed in the ovary [17]. AMH in the female is first observed in the postnatal granulosa cells of the recruited primordial follicles. Both quality and quantity of follicles decrease over time in conjunction with serum AMH concentrations until AMH becomes undetectable at or around menopause in the human female [16] [25] [32] [33].

In comparison to males, females have a gradual decrease in AMH concentration throughout their life [31]. In the case of a twin pregnancy with heterosexual births in cattle, the female fetus is exposed to AMH during gestation (produced by the testes (Sertoli cells) of its male twin, which circulates through placental vascular anastomoses), resulting in regression of the Müllerian duct (also between day 50 and 80) [31] in the female. The resulting syndrome is termed freemartin in the female and thus, she maybe infertile.

The present study aims to define the relationship of serum AMH concentration and ova production from cattle in a superovulatory regimen. Several objectives to support the aim of this study were to evaluate the influence of age and breed on serum AMH concentration. Would it be possible to utilize AMH concentration as a predictor of ova collection in cattle? With the possibility of predicting ovarian (ova collection) response using serum $\mathrm{AMH}$ as a predictor, we aspire to use this knowledge to better formulate FSH regimens to maximize a donor's ova production. If this is true, this would translate into better embryo production and become more profitable for the producer. This may be accomplished by being able to reduce the amount of FSH used in order to prevent overstimulation and increase production in those donors identified as potential poor producers if $\mathrm{AMH}$ is truly correlated with ova production. Preventing 
overstimulation and increasing ova production would be beneficial in cost and overall ova production.

\section{Materials and Methods}

There were 369 data points across 6 breeds (Angus, Beefmaster, Brahman, Black Brangus, Red Brangus, and Wagyu) that were used for analyzing the relationship of serum AMH concentrations and total ova production. All donor females were enrolled in an embryo transfer program by Ovagenix. Enrolled animals were assigned an embryo collection date, females were synchronized with a CIDR protocol and stimulated with commercially available follicle stimulating hormone (FSH, Pluset or Follitropin V). Breed type, age, weight, body condition score, flush history (if available), and ovarian ultrasonography were all used in formulating a FSH regimen. All ova/embryos collected in this study resulted from the nonsurgical recovery 6.5 - 7.5 days after estrus (Day 0). All flushes were collected into sterile, disposable filters, and ova/embryos were identified in the filtrate by stereo microscopy with illumination from underneath at a magnification of at least $50 \times$ by Ovagenix staff. Commercially available Heat Watch (CowChips, LLC Manalapan, NJ) was used to monitor estrus behavior (heat). Collectively, 3 to 4 units of semen were used for artificial insemination (AI) at 12 and 24 hours post onset of estrus (heat). Blood samples were taken from donor cows through tail bleeding at the time of embryo collection (day 7). Samples were centrifuged at $10,000 \mathrm{rpm}(2500 \mathrm{~g})$ for 10 minutes and the serum collected with disposable pipettes. The serum was aliquotted into two $1.5 \mathrm{~mL}$ microtubes and frozen $\left(-20^{\circ} \mathrm{C} \pm 2{ }^{\circ} \mathrm{C}\right)$. Assays were performed by enzyme linked immunosorbant assay (ELISA) with a bovine specific AMH assay supplied from ANSH Labs. Results were obtained using a Micromedics $\mathrm{V}_{\max }$ Plate Reader at 450 angstrom wave length. Table 1 represents a typical FSH stimulation regimen.

\section{Results}

Analysis included effect of age, breed, and $\mathrm{AMH}$ on the total ova production. We treated the total ova production as a continuous variable, and used an analysis of

Table 1. Representation of a typical FSH regimen used in this study.

\begin{tabular}{ccc}
\hline Day & Hour & Procedure \\
\hline 0 & A.M. & CIDR + Combo \\
$4-5$ & A.M. & FSH \\
$4-5$ & P.M. & FSH \\
6 & A.M. & FSH, PGF2 $\alpha$ \\
6 & P.M. & FSH, PGF2 $\alpha$ \\
7 & A.M. & FSH, CIDR-out \\
8 & Expect heat & Cystorelin at onset of estrus \\
$8-9$ & $+12 \& 24$ hrs post estrus & AI \\
\hline
\end{tabular}


covariance (ANCOVA) for our methodology to determine significance (Table 2). For this analysis, we excluded all the Wagyu cattle due to not having enough variability of age within this breed.

The results indicate that age is clearly one important predictor for total ova production [5]. The limitations of ANCOVA analysis include 1) treating total ova production as a continuous variable and 2) the observed distribution of age or AMH concentration differs across breed. For the actual model fitting to the count data, one may initially think of the Poisson model. However, due to the presence of over dispersion in the data, we fit the negative binomial model and report the results here (Table 3 ):

Call:glm.nb (formula $=y \sim$ Age $+z+$ amh, init.theta $=1.746650516$, link $=$ $\log )$

The results indicate that age is clearly one important predictor for total ova production [22]. The limitations of ANCOVA analysis include 1) treating total ova production as a continuous variable and 2) the observed distribution of age or $\mathrm{AMH}$ concentration differs across breed.

Deviance Residuals: Min: -2.9317 1Q: -0.8358 Median: -0.1431 3Q: 0.4306 Max: 2.2548

Theta: 1.747

Std. Err.: 0.154

$2 \times \log$-likelihood: -2411.523

The results clearly indicate that both age and AMH concentration have significant effect at the $(\mathrm{P}<0.05)$ level on the total ova production. Explanatory variable breed is presented in the model via the dummy variables $Z_{0}, Z_{1}, Z_{3}, Z_{4}$. However, breed does not have any effect on the ova production. This analysis excluded

Table 2. ANCOVA of age, breed, and AMH.

\begin{tabular}{cccccc}
\hline & DF & Sum Sq & Mean Sq & F value & $\operatorname{Pr}(>\mathrm{F})$ \\
\hline Age at collection & 1 & 885 & 884.5 & 7.398 & 0.0068 \\
Breed & 4 & 874 & 218.5 & 1.828 & 0.12313 \\
AMH & 1 & 269 & 269.1 & 2.251 & 0.13452 \\
\hline
\end{tabular}

Table 3. Negative binomial model.

\begin{tabular}{ccccc}
\hline & Estimate & Std. error & Z value & $\operatorname{Pr}(>\mathrm{z})$ \\
\hline (Intercept) & 2.68913 & 0.17654 & 15.233 & $<2 \mathrm{e}-16$ \\
Age & -0.03979 & 0.01524 & -2.61 & 0.00905 \\
Breed 4 & 2.1459 & 0.19153 & 1.12 & 0.26254 \\
Breed 1 & -0.05409 & 0.20936 & -0.258 & 0.79615 \\
Breed 3 & 0.0475 & 0.19871 & 0.239 & 0.81077 \\
Breed 0 & 0.18326 & 0.21084 & 0.869 & 0.38473 \\
AMH & 0.14808 & 0.05939 & 2.493 & 0.01265 \\
\hline
\end{tabular}


all Wagyu subjects as age was not available for all Wagyu cattle and there was not enough variability in the age when they were observed. Next, we analyzed the data using all breeds and consequently excluding age from the model (Table 4).

Call:glm.nb (formula $=$ a $\$$ Total.Ova $\sim$ breed $+\mathrm{a} \$ \mathrm{AMH}$, init.theta $=$ $1.753309155, \operatorname{link}=\log$ )

Deviance Residuals: Min: -2.9278 1Q: -0.8386 Median: -0.1948 3Q: 0.4092 Max: 2.2705

Theta: 1.753

Std. Err.: 0.147

$2 \times$ log-likelihood: -2621.745

Serum AMH has a statistically significant effect $(\mathrm{P}<0.05)$. Breed turned out to be not a significant predictor for the total ova production. Of course, there are several limitations of the analysis. First, the distribution of age within the breeds is not the same creating an imbalance in the analysis. Second, the distribution of AMH across the breed is not homogeneous. Thus, the results should be interpreted cautiously. Since the data contained 112 Beefmaster and 103 Brahman cattle, a sizeable proportion compared to the other breeds and both of these breeds contain sufficient variability in terms of age, we ran a further analysis using only these two breeds. In this analysis, we investigated if there was any change-point in the AMH concentration. We created two predictors out of AMH concentrations as follows: $X_{1}=\mathrm{AMH} \times I(\mathrm{AMH}<r)$ and $X_{2}=\mathrm{AMH} \times I$ $($ AMH $>r)$. We took different values of $\mathrm{r}$ and chose the best $\mathrm{r}$ based on the minimum Akaike's Information Criterion (AIC) criteria. The optimum $r$ came out to be 1.9 and the results of the analysis are given below (Table 5).

Table 4. Negative binomial model excluding age.

\begin{tabular}{ccccc}
\hline & Estimate & Std. error & Z value & $\operatorname{Pr}(>\mathrm{z})$ \\
\hline (Intercept) & 2.50695 & 0.16502 & 15.192 & $<2 \mathrm{e}-16$ \\
Breed 4 & 0.11402 & 0.18477 & 0.617 & 0.53717 \\
Breed 1 & -0.06476 & 0.20903 & -0.31 & 0.75672 \\
Breed 3 & -0.11324 & 0.18507 & -0.612 & 0.54064 \\
Breed 0 & 0.05542 & 0.20362 & 0.272 & 0.78549 \\
AMH & -0.32661 & 0.21952 & -1.488 & 0.1368 \\
\hline
\end{tabular}

Table 5. Negative binomial model using Akaike's information criterion and focusing only on Brahman and Beefmaster.

\begin{tabular}{ccccc}
\hline & Estimate & Std. error & $\mathrm{Z}$ value & $\operatorname{Pr}(>\mathrm{z})$ \\
\hline Intercept & 2.82331 & 0.18796 & 15.021 & $<2 \mathrm{e}-16$ \\
$\mathrm{AMH}<1.9$ & 0.40037 & 0.12905 & 3.103 & 0.001919 \\
$\mathrm{AMH}>1.9$ & 0.02359 & 0.09588 & -0.246 & 0.805681 \\
Age at Collection & 0.0621 & 0.01697 & -3.66 & 0.000252 \\
\hline
\end{tabular}


Call:

glm.nb (formula $=$ newa $\$$ Total.Ova $\sim x_{1}+x_{2}+$ newa $\$$ Age.at.Collec, ,init.theta $=$ 1.814469429, link $=\log )$

Deviance Residuals: Min: -3.0807 1Q: -0.8881 Median: -0.1285 3Q: 0.4413 Max: 1.9598

Theta: 1.814

Std. Err.: 0.204

$2 \times$ log-likelihood: -1543.966

Analyzing the data showed a cutoff AMH concentrations within each breed where donors above the given concentration can be deemed better ova producers than females below a certain concentration of AMH. For the 25 Angus donors, those that were below $0.25 \mathrm{ng} / \mathrm{ml}$ had an average of 10.07 ova per flush, while those above $0.25 \mathrm{ng} / \mathrm{ml}$ gave 17.2 ova per flush, as shown in Figure 2(a). Out of the 103 Brahman donors, the 50 females with AMH concentrations less than $0.70 \mathrm{ng} / \mathrm{ml}$ averaged 8.28 ova per flush, while the 53 cows above $0.70 \mathrm{ng} / \mathrm{ml}$ averaged 16.96 ova per flush, as shown in Figure 1. Of the 111 Beefmaster donors, those less than $0.30 \mathrm{ng} / \mathrm{ml}$ averaged 9.0 total ova per flush, while those above $0.30 \mathrm{ng} / \mathrm{ml}$ gave 17.2 ova per flush, as shown in Figure 2(c). We viewed the Brangus together and separate (Red Brangus and Black Brangus). Since their breed makeup is closely related, it was to our expectation that results would show the same cutoff AMH concentration. Combining the red and black Brangus, there were 96 animals. Donors below $0.70 \mathrm{ng} / \mathrm{ml}$ of AMH produced 10.89 ova per flush while the females whose concentration for AMH was above 0.70 $\mathrm{ng} / \mathrm{ml}$ gave 17.18 ova per flush, as shown in Figure 2(d). Separately, the numbers were 9.11, 17.7, 13.39, and 17.39 for black Brangus below $0.70 \mathrm{ng} / \mathrm{ml}$, black Brangus above $0.70 \mathrm{ng} / \mathrm{ml}$, red Brangus below $0.70 \mathrm{ng} / \mathrm{ml}$ and red Brangus above $0.70 \mathrm{ng} / \mathrm{ml}$, respectively. The $32 \mathrm{Wagyu}$ collections resulted in a cutoff concentration for AMH of $0.30 \mathrm{ng} / \mathrm{ml}$ for donors that were arbitrarily assigned as good versus poor ova donors. Donors with AMH concentrations that were below 0.30 $\mathrm{ng} / \mathrm{ml}$ averaged 7.39 total ova per flush while the females greater than $0.30 \mathrm{ng} / \mathrm{ml}$ produced 12.14 ova per flush, as shown in Figure 2(b).

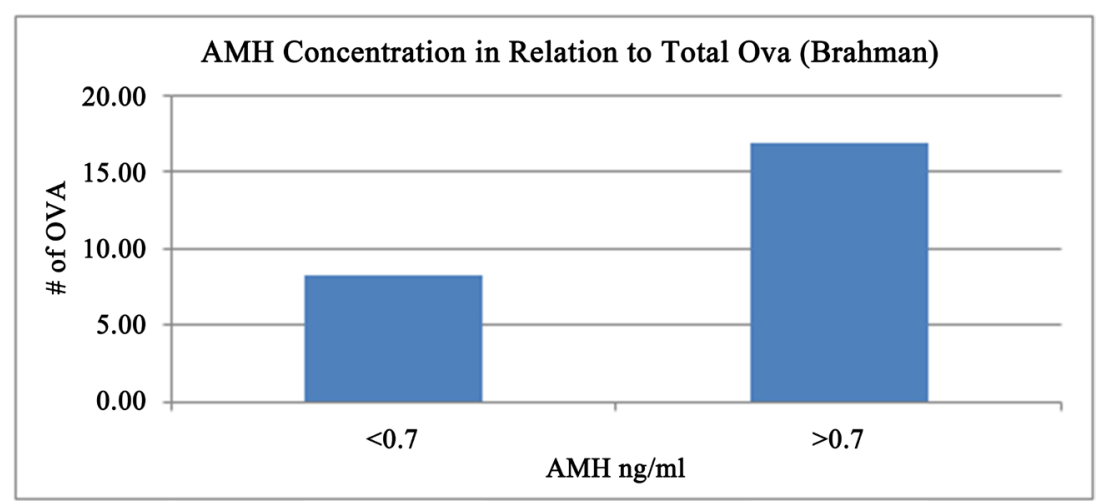

Figure 1. Total ova produced by Brahman donors, separated by those below and above the $\mathrm{AMH}$ cutoff concentration. 


\section{Discussion}

Results demonstrate that $\mathrm{AMH}$ concentration is highly correlated to total ova collected in a superovulation program (the greater the $\mathrm{AMH}$, the greater number of ova collected). In comparison, cows with greater AMH concentrations had better ovulatory responses to FSH treatment (more ova collected) as hypothesized than cows with lower AMH concentrations. However, as expected there are many factors associated with success or failure in an embryo transfer program. Variability in an embryo transfer program is always a concern and what can be done to minimize that variability is subjective in most cases. Some of the inconsistency when the data is viewed as a whole is attributed to the fact that the $\mathrm{AMH}$ concentration chosen as a cutoff for above average ova producers cannot be considered the same across breeds, much like expected progeny differences (EPDs) (Table 6). In Brahman cattle, for example, the results show $0.70 \mathrm{ng} / \mathrm{ml}$ appears to be an appropriate boundary. Out of 103 females, there were 50 donors with an AMH concentration below $0.70 \mathrm{ng} / \mathrm{ml}$ and they averaged 8.28 total ova per flush. There were 53 donors with a value greater than $0.70 \mathrm{ng} / \mathrm{ml}$, which had an average of 16.96 ova per collection. In Wagyu cattle, there were six females that were above the $0.70 \mathrm{ng} / \mathrm{ml}$ out of 32 . The cutoff $\mathrm{AMH}$ concentration results show the more appropriate cutoff concentration at $0.30 \mathrm{ng} / \mathrm{ml}$ providing evidence that one AMH concentration cannot be utilized across breeds. Breed

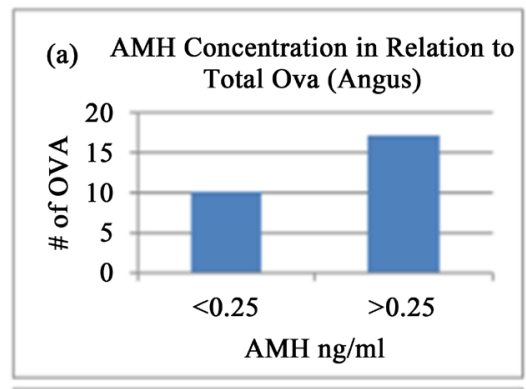

(c) AMH Concentration in Relation to

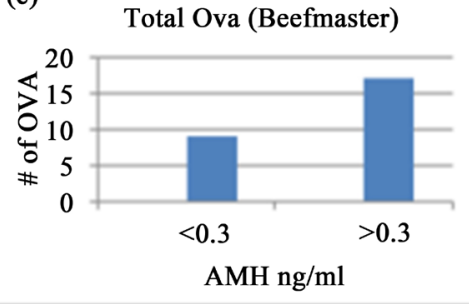

(b) AMH Concentration in Relation to

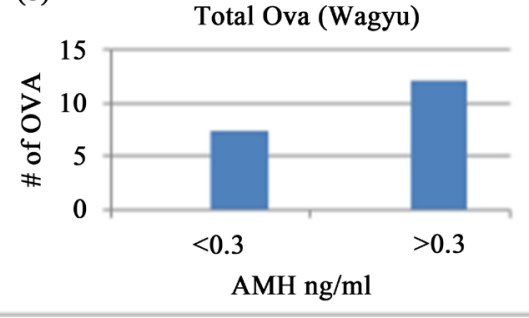

(d) $\mathrm{AMH}$ Concentration in Relation to Total Ova (Brangus Combined)

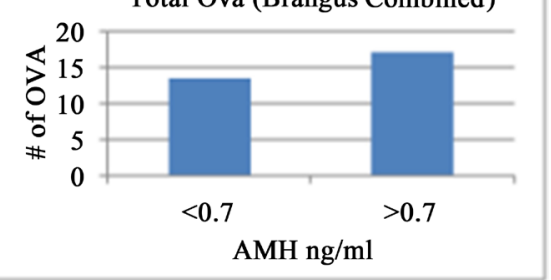

Figure 2. In order, total ova produced by: (a) Angus, (b) Wagyu, (c) Beefmaster, and (d) Brangus donors, separated by those below and above the AMH cutoff concentration for their respective breed.

Table 6. Mean age of donors at time of collection and standard deviation.

\begin{tabular}{ccccccc}
\hline & Angus & Brahman & Brangus & Beefmaster & Wagyu & All breeds \\
\hline Mean Age & 3.94 & 8.57 & 5.71 & 7.97 & $<3.0$ & 7.16 \\
Std Dev & 1.72 & 3.11 & 3.029 & 10.85 & n/a & 6.92 \\
\hline
\end{tabular}


specific ranges and possibly age related changes should be evaluated carefully.

The FSH regimen a donor receives is another major contributor towards the variability in ova collection. Currently, there is not a science in prescribing an exact dosage of FSH to maximize ova production in a donor cow. Overstimulation results in a large majority of the ova either unfertilized or degenerate, while "under-stimulation" does not maximize the donor's ability or capitalize the expense and efforts of embryo transfer superovulatory program. Many embryo transfer companies use ultrasonography of follicles at the time of CIDR insertion, breed type, and flush history to try and predict the correct dosages of FSH to maximize stimulation of the ovary and recovery of embryos. There are many variables that cannot be accounted for and therefore lead to decrease superovulatory response and hence embryo recovery, especially first time donors. However, the more a donor cow is flushed, the better a skilled embryologist can prescribe the correct FSH dosage to a female and maximize embryo production. Another contributing factor would be the lot of FSH used for stimulation. Being that the current FSH available is a pituitary derived porcine product and different lots could have different potencies make knowing animal history important and utilizing other tools to try and better formulate FSH regimens. At some point in time there will have to be a standard developed for potency, which currently can and does affect the follicular response. It is predicted the AMH concentration will be used in conjunction with breed type and flush history (if available) to take some of the guesswork out of assigning FSH regimens and maximize the production of ova, especially on animals beginning an FSH regimen for their first time in a superovulation program.

As we become more familiar with AMH concentration in association with age and ova production, this will be another tool to help determine ova production in response to superovulation. As mentioned earlier, with each estrous cycle, the number of follicles in the antral follicle pool is reduced until menopause, and thus the AMH concentrations is reduced as the animal ages [32]. Can we optimize the FSH regimen knowing the AMH concentration prior to administration of FSH? In other reports, in both humans and animals [25] [32] [31] the decline in AMH is gradual up to a point. Where the break for good ova donors vs a poor ova donors will certainly be variable based on age, but where that break may occur and be most beneficial will be answered in future experiments in relation to $\mathrm{AMH}$ concentration. This decline in AMH concentration could be accountable for variance in cattle as it is in the human female with respect to ova production [17] [25] [29] [34]. These results indicate that age clearly has a significant effect on the total ova production. More importantly, we see the total ova production is significantly $(\mathrm{P}<0.05)$ associated with the $\mathrm{AMH}$ concentration; the higher the $\mathrm{AMH}$, the greater number of ova.

We believe with an increased number of data points across other breeds, the results will shift towards more definitive results with respect to age and AMH concentration. There are simply too many variables at play when observing 
small numbers of animals. From this study, it appears that AMH concentration, even in the breeds with a limited number of animals can be a useful tool in trying to predict ova production in response to a superovulatory regimen. This would allow one to save time and money by using $\mathrm{AMH}$ concentration as a predictor of ova production before beginning a superovulation regimen which should result in decreasing "over stimulation or under stimulating" the ovary of the donor animals and maximizing FSH use and limiting expense of FSH.

\section{Conflicts of Interest}

The authors declare no conflicts of interest regarding the publication of this paper.

\section{References}

[1] Donaldson, L. (1984) Embryo Production in Superovulated Cows: Transferable Embryos Correlated with Total Embryos. Theriogenology, 21, 517-524. https://doi.org/10.1016/0093-691X(84)90436-9

[2] Hasler, J.F. (2003) The Current and Future of Commercial Embryo Transfer in Cattle. Animal Reproduction Science, 79, 245-264. https://doi.org/10.1016/S0378-4320(03)00167-2

[3] Durocher, J., Morin, N. and Blondin, P. (2006) Effect of Hormonal Stimulation on Bovine Follicular Response and Oocyte Developmental Competence in a Commercial Operation. Theriogenology, 65, 102-115. https://doi.org/10.1016/j.theriogenology.2005.10.009

[4] Hasler, J. (2001) Factors Affecting Frozen and Fresh Embryo Transfer Pregnancy Rates in Cattle. Theriogenology, 56, 1401-1415. https://doi.org/10.1016/S0093-691X(01)00643-4

[5] Moniaux, D., Chupin, D. and Saumande, J. (1983) Superovulatory Responses of Cattle. Theriogenolgy, 19, 55-81. https://doi.org/10.1016/0093-691X(83)90124-3

[6] Adams, G.P. (1994) Control of Ovarian Follicular Wave Dynamic in Cattle: Implications for Synchronization and Superstimulation. Theriogenolgy, 41, 19-24. https://doi.org/10.1016/S0093-691X(05)80044-5

[7] Ginther, O.J., Kastelie, J.P. and Knopf, L. (1989) Composition and Characteristics of Follicular Waves during the Bovine Estrous Cycle. Animal Reproduction Science, 20, 187-200. https://doi.org/10.1016/0378-4320(89)90084-5

[8] Kawamata, M. (1994) Relationships between the Number of Small Follicles Prior to Superovulatory Treatment and Superovulatory Response in Holstein Cows. Journal of Veterinary Medical Science, 56, 965-967. https://doi.org/10.1292/jvms.56.965

[9] Ko, J.C.H., Kastelic, J.P., Del Campo, M.R. and Ginther, O.J. (1991) Effects of a Dominant Follicle on Ovarian Follicular Dynamics during the Estrous Cycle in Heifers. Journal of Reproduction and Fertility, 91, 511-519. https://doi.org/10.1530/jrf.0.0910511

[10] Takahashi, M., Hayashi, M., Manganaro, T.F. and Donahoe, P.K. (1986) The Ontogeny of Mullerian Inhibiting Substance in Granulosa Cells of the Bovine Ovarian Follicle. Biolology of Reproduction, 35, 447-453. https://doi.org/10.1095/biolreprod35.2.447

[11] Senger, P.L. (2005) Pathways to Pregnancy and Parturition. 2nd Edition, Current Conceptions, Inc., Pullman. 
[12] Kumar, A., Kalra, B., Patel, A., McDavid, L. and Roudebush, W.E. (2010) Development of a Second Generation anti Mullerian Hormone ELISA. Journal of Immunological Methods, 362, 51-59. https://doi.org/10.1016/j.jim.2010.08.011

[13] Savio, J.D., Keenan, L., Boland, M.P. and Roche, J.F. (1988) Pattern of Growth of Dominant Follicles during the Oestrous Cycle of Heifers. Journal of Reproduction and Fertility, 83, 663-671. https://doi.org/10.1530/jrf.0.0830663

[14] Sirois, J. and Fortune, J.E. (1988) Ovarian Follicular Dynamics during the Estrous Cycle in Heifers Monitored by Real-Time Ultrasonography. Biolology of Reproduction, 39, 308-317. https://doi.org/10.1095/biolreprod39.2.308

[15] Fair, T., Hulshof, S.C., Hyttel, P., Greve, T. and Boland, M. (1997) Oocyte Ultrastructure in Bovine Primordial to Early Tertiary Follicles. Anatomy and Embryolo$g y$, 195, 327-336. https://doi.org/10.1007/s004290050052

[16] Rota, A., Ballarin, C., Vigier, B., Cozzi, B. and Rey, R. (2002) Age Dependent Changes in Plasma Anti-Müllerian Hormone Concentrations in the Bovine Male, Female, and Freemartin Differentiation. General and Comparative Endocrinology, 129, 39-44. https://doi.org/10.1016/S0016-6480(02)00514-2

[17] Wandji, S.A., Srsen, V., Voss, A.K., Eppig, J.J. and Fortune, J.E. (1996) Initiation in Vitro Growth of Bovine Primordial Follicles. Biology of Reproduction 55, 942-948. https://doi.org/10.1095/biolreprod55.5.942

[18] Muttukrishna, S., Suharjono, H., McGarrigle, H. and Sathanandan, M. (2004) Inhibin $\mathrm{B}$ and Anti-Mullerian Hormone: Markers of Ovarian Response in IVF/ICSI Patients. BJOG: An International Journal of Obstetrics and Gynaecology, 111, 1248-1253. https://doi.org/10.1111/j.1471-0528.2004.00452.x

[19] Cushman, R.A., DeSouza, J.C., Hedgpeth, V.S. and Britt, J.H. (1999) Superovulatory Response of One Ovary Is Related to the Micro- and Macroscopic Population of Follicles in the Contralateral Ovary of the Cow. Biolology of Reproduction, 60, 349-354. https://doi.org/10.1095/biolreprod60.2.349

[20] Ireland, J.J., Ward, F., Jimenez-Krassel, F., Ireland, J.L., Smith, G.W., Lonergan, P. and Evans, A.C. (2007) Follicle Numbers Are Highly Repeatable within Individual Animals But Are Inversely Correlated with FSH Concentrations and the Proportion of Good-Quality Embryos after Ovarian Stimulation in Cattle. Human Reproduction, 22, 1687-1695. https://doi.org/10.1093/humrep/dem071

[21] Knopf, L., Kastelic, J.P., Schallenberger, E. and Ginther, O.J. (1989) Ovarian Follicular Dynamics in Heifers: Test of Two-Wave Hypothesis by Ultrasonically Monitoring Individual Follicles. Domestic Animal Endocrinology, 6, 111-119. https://doi.org/10.1016/0739-7240(89)90040-4

[22] Monniaux, E., Clement, F., Dalbies-Tran, R., Estienne, A., Fabre, S., Mansanet, C. and Monget, P. (2014) The Ovarian Reserve of Primordial Follicles and the Dynamic Reserve of Antral Growing Follicles: What Is the Link? Biolology of Reproduction, 90, 85. https://doi.org/10.1095/biolreprod.113.117077

[23] Durlinger, A.L., Visser, J.A. and Themmen, A.P. (2002) Regulation of Ovarian Function: The Role of Anti-Müllerian Hormone. Reproduction, 124, Article ID: 601124. https://doi.org/10.1530/rep.0.1240601

[24] Orvis, G.D. and Behringer, R.R. (2007) Cellular Mechanisms of Müllerian Duct Formation in the Mouse. Developmental Biology, 306, 493-504. https://doi.org/10.1016/j.ydbio.2007.03.027

[25] Rodgers, R.J. and Irving-Rodgers, H.F. (2010) Morphological Classification of Bovine Ovarian Follicles. Journal of Reproduction, 139, 309-318.

https://doi.org/10.1530/REP-09-0177 
[26] Vigier, B., Tran, D., Legeai, L., Bezard, J. and Josso, N. (1984) Origin of Anit-Mullerian Hormone in Bovine Freemartin Fetuses. Journal of Reproduction and Fertility, 70, 473-479. https://doi.org/10.1530/jrf.0.0700473

[27] Rico, C., Fabre, S., Me'digue, C., Clemente, N., Cle'ment, F., Bontoux, M., Touze, J., Dupont, M., Briant, E., Re'my, B., Beckers, J. and Monniaux, D. (2009) Anti-Mullerian Hormone Is an Endocrine Marker of Ovarian Gonadotropin-Responsive Follicles and Can Help to Predict Superovulatory Responses in the Cow. Biological Reproduction, 80, 50-59. https://doi.org/10.1095/biolreprod.108.072157

[28] Cate, R.L., Mattaliano, R.J., Hession, C., Tizard, R., Farber, N.M., Cheung, A., Ninfa, E.G., Frey, A.Z., Gash, D.J. and Chow, E.P. (1986) Isolation of the Bovine and Human Genes for Müllerian Inhibiting Substance and Expression of the Human Gene in Animal Cells. Cell, 45, 685-698. https://doi.org/10.1016/0092-8674(86)90783-X

[29] Durlinger, A.L., Gruijters, M.J., Kramer, P., Karels, B., Ingraham, H.A., Nachtigal, M.W., Uilenbroek, J.T., Grootegoed, J.A. and Themmen, A.P. (2002) Anti-Müllerian Hormone Inhibits Initiation of Primordial Follicle Growth in the Mouse Ovary. Endocrinology, 143, 1076-1084. https://doi.org/10.1210/endo.143.3.8691

[30] Kastelic, J.P., Ko, J.C.H. and Ginther, O.J. (1990) Suppression of Dominant and Subordinate Ovarian Follicles by a Pmteinaceous Fraction of Follicular Fluid in Heifers. Theriogenology, 34, 499-509. https://doi.org/10.1016/0093-691X(90)90007-G

[31] Visser, J.A. and Themmen, A.P.N. (2005) Anti-Mullerian Hormone and Folliculogenesis. Mollecular and Cellular Endocrinology, 234, 81-86. https://doi.org/10.1016/j.mce.2004.09.008

[32] Ficicioglu, C., Kutlu, T., Baglam, E. and Bakacak, Z. (2006) Early Follicular Antimullerian Hormone as an Indicator of Ovarian Reserve. Fertility and Sterility, 85, 592-596. https://doi.org/10.1016/j.fertnstert.2005.09.019

[33] Lerner, S.P., Thayne, W.V., Baker, R.D., Henschen, T., Meredith, S., Inskeep, E.K., Dailey, R.A., Lewis, P.E. and Butcher, R.L. (1986) Age, Dose of FSH and Other Factors Affecting Superovulation in Holstein Cows. Journal of Animal Science, 63, 176-183. https://doi.org/10.2527/jas1986.631176x

[34] Baarends, W.M., Uilenbroek, J.T., Kramer, P., Hoogerbrugge, J.W., van Leeuwen, E.C., Themmen, A.P. and Grootegoed, J.A. (1995) Anti-Müllerian Hormone and Anti-Müllerian Hormone Type II Receptor Messenger Ribonucleic Acid Expression in Rat Ovaries during Postnatal Development, the Estrous Cycle, and Gonadotropin-Induced Follicle Growth. Endocrinology, 136, 4951-4962.

https://doi.org/10.1210/endo.136.11.7588229 